\title{
局所発汗量と蒸汗量の同時測定と 局所蒸発熱伝達率の算出法
}

MEASUREMENTS OF LOCAL SWEAT RATES AND EVAPORATION RATES AND THE DIRECT DETERMINATION OF LOCAL EVAPORATIVE HEAT TRANSFER COEFFICIENTS

\author{
垣 鍔 直*, 勝 浦 哲夫** \\ Naoshi KAKITSUBA and Tetsuo KATSUURA
}

Local calorimetry was studied using a device to measure local evaporation rates ( $\dot{\mathbb{m}}_{\mathbf{z}}$ ) and a ventilated capsule to measure local sweat rates $\left(\dot{\mathbf{m}}_{\mathbf{s w}}\right)$. Changes in $\dot{\mathbf{m}}_{\mathbf{s w}}$ and $\mathbb{m}_{\mathbf{s k}}$ at chest, forearm and front thigh were observed while two young male subjects were exposed to the heat $\left(46-48^{\circ} \mathrm{C}\right.$ ) for 1 hour. During the first 30-40 minutes, $\dot{\mathrm{m}}_{3 \mathrm{k}}$ increased progressively with $\dot{\mathrm{m}}_{\mathbf{s}}$ and became appreciably less than $\dot{\mathrm{m}}_{\mathrm{sw}}$ when the skin was fully wetted. Thus, the critical $\dot{\mathrm{m}}_{\mathrm{sk}}$ value can be clearly defined so as to determine local evaporative heat transfer coefficients.

keywords: sheat evaporation, convection, sweating, evaporative heat transfer coefficient 蒸汗、対流、発汗、蒸発熱伝達率

1.はじめに

局所蒸汗量に関する研究は、近年の小型電気式湿度セ ンサの開発に負うところが大きい。先駆的な研究として はL a m k e らの研究1) 2'が挙げられる。研究成果をも とに開発された測定器は、現在では市販され臨)㮏や研究 に広く利用されている。測定原理は皮膚面近椦の 2 点の 相対湿度と温度を測定し、2 点間の絶対湿度勾配から蒸 汗量を求める方法で、勾配法と呼ばれている。しかし、 有風時の水蒸気濃度勾配は皮潧面からの距離の高次関数 となることが知られているが、それを直線で近似するた めに蒸汗量を過小評価する欠点が指適されている3゙。

勾配法の欠点を解消するために、筆者らは境界層内の 3 点の相対湿度と温度を测定できる測定器(局所カロリメ 一夕と呼称)を開発した ${ }^{4 !}$ 。水蒸気㴗度勾配と温度勾配を 皮轤面からの距離の二次関数に近似できるので、理論上 は蒸発量や対流による放受熱量の真值に近い值が求めら れる。さらに、実験式から皮倜面の絶対湿度や皮周温度 も間接的に測定できる特徵がある。既に、試作器を用い た実験的研究により測定器の信頼性を確かめている。
局所発汗量に関する研究も応答の速い電気式湿度セン サの開発に負うところが大きい。皮成に密着した小型の カプセルに一定流量の乾燥ガスを流し、回収したガスの 温度と相対湿度を測定することで発汗量を求める方法が 一般的である。この測定方法により数多く0研究成果が 得られている51.67.7)。しかし、局所の発汗量と蒸汗量 を同時に測定した研究は見当たらない。そこで、被蚞者 を暑熱㻴境に曝露した時の局所発汗量と蒸汗量を同時測 定し、無効発汗の発現を確認した。また、皮膚面が完全 にぬれた状態を直接確認することにより局所蒸発熱云達 率を算出したのでここに報告する。

\section{2. 局所蒸汗量及び対流放受熱量の測定原理}

局所カロリメータ（詳細は文献 4 参照）の測定原理を 簡単に説明する。感知部は図 1 に示す構造で、保護枠内 に3 個の小型相対湿度センサを組み込み、感湿面を皮庴 面に垂直にし、その中心が 5、8、1 1 mmなるように配 置してある。さらに、各湿度センサ中央部近傍に温度セ
* 豊田工業高等専門学校建築学科 助教授・工博

** 千葉大学工学部工業意匠学科 助教授 · 理博
Assoc. Prof., Dept. of Architecture, Toyota College of Technology, Dr. Eng.

Assoc. Prof., Dept. of Ergonomics, Faculty of Engineering, Chiba Univ., Ph. D 
ンサ配置して各点の絶対湿度が求められる橑造とした。 使用したセンサは、測定簯囲 0 $100 \%$ 、精度 $\pm 2 \%$ 、 時定数 1 秒 (90\%応答) の相対湿度センサ（HM15041、 $n^{*}$ 价社）と、測定䉇囲 $-20 \sim 80^{\circ} \mathrm{C}$ 、綪度 $\pm 0.2^{\circ} \mathrm{C}$ 、 $0 \rightarrow 100^{\circ} \mathrm{C}$ に対する時定效 1 . 6 秒の白金測温体 (Pt $100 \Omega$ ）を使用した。

図 2 に境界層内の絶対湿度と温度のプロフィールを示

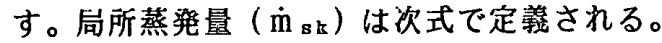

$$
\begin{gathered}
\dot{\mathrm{m}}_{\mathrm{sk}}=\mathrm{D}_{\mathrm{w}} \times(\delta \rho / \delta \mathrm{X}) \quad\left(\mathrm{g} / \mathrm{m}^{2} \cdot \mathrm{h} \mathrm{r}\right) \\
\text { ここに、 } \mathrm{D}_{w}=\text { 拡散係数 }\left(\mathrm{m}^{2} / \mathrm{h} \mathrm{r}\right) \\
\rho=\text { 絶対湿度 }\left(\mathrm{g} / \mathrm{m}^{3}\right) \\
\mathrm{X}=\text { 表面か } 5 \text { の距離 }(\mathrm{m})
\end{gathered}
$$

また、局所対流放受熱量（ $q_{c} ）$ は次式で定義される。

$$
\begin{gathered}
\mathrm{q}=\lambda \times(\delta \theta / \delta \mathrm{x}) \quad\left(\mathrm{kca} \ell / \mathrm{m}^{2} \cdot \mathrm{h} \mathrm{r}\right) \\
こ こ に 、 \lambda=\text { 熱伝導率 }\left(\mathrm{kca} \ell / \mathrm{m} \cdot \mathrm{h} \mathrm{r} \cdot{ }^{\circ} \mathrm{C}\right) \\
\theta=\text { 温度 }\left({ }^{\circ} \mathrm{C}\right)
\end{gathered}
$$

実駼式 $\rho(\mathrm{X}) 、 \theta(\mathrm{X})$ から、 $\delta \rho / \delta \mathrm{X} 、 \delta \theta / \delta \mathrm{x}$ が得 5 れるので、上式群から甶 $\mathrm{sk}$ と $\mathrm{q}$ cが算出できる。また、 $\rho$ $(\mathrm{X}) 、 \theta(\mathrm{X})$ にX=0 を代入した值が皮閶面の絶対湿度や皮 弧温度に相当することになる。

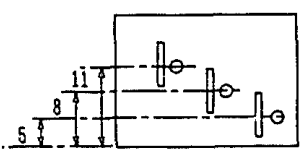

a:thermlstors b:humidtty sensors

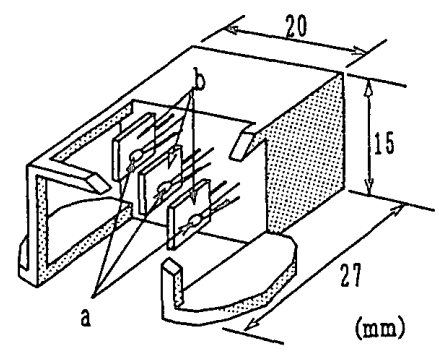

(mm)
図 1 局所カロリメー夕感知部のセンサ配置図

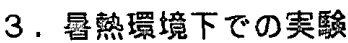

\section{$3-1$. 実駼内容及び測定項目}

千葉大学工学部工業意匠学科内の人工気候室で実駼を 行った。健康な男性被㛟者 2 名の局所の蒸汗是、発汗量、 鶖流量、直晹温、皮居温（Hardy-DuBoisの 7 点法）を 1 分間隔で連続測定し、曝露前後の体重減少量、旿露中の 然効発汗量も測定した。1回の実駼に1人の被娭者を対 象とし、苲汗星と発汗星は右胸、右大腿前部中央、右前 䛷中央を 1 回に 1 ケ所ずつ測定した。従つて、被㛟者 1 人当たり 3 回の実駼を行った。

発汗冝の測定には換気カプセル法を用い、カプセルに

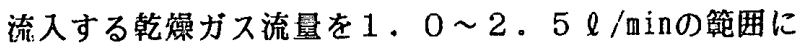
制御した。カプセルから回收されたガスの相対湿度と温 度をデータ集録装置(サー歹”叻6、江臊電気)に接続し、G PI B ボードを介してパーソナルコンピュータ(NEC-PC9
801)に幹咲して收録いた。局所方ロリメータと熱流セン サ(Kemtherm HMF-101、京都電子工業)は換気カプセルに 際合う位置に取り付け、データ収録は発汗量の測定と同 樣にテータ集録装置によるオンラインで行った。直腸温 と皮剧温は専用サーミス夕を用いた。それらを多点温度 集録装置(1623、テクノセブン)に接続し、G P I B ボー ドを介しパーソナルコンピュータで収録した。祭露前後 の体重は精密体重計(B-2、神戸スケール社)で測定し、そ の結果から体重減少量を求めた。また、曝露前後の着衣 (トランクスのみ)の重悬と床面と体表面の汗を拭き取 った夕オルの重量を精密天秤(FA2000、A＆D社)で測定し、 無効発汗量はそれらの重凅差の台計として求めた。

\section{3-2. 実駩手順}

被検者は $27^{\circ} \mathrm{C}$ 前後の前室で 30 分間滞在し、その後 に気温 $48^{\circ} \mathrm{C}$ 、相対湿度 $50 \%$ に制御した人工氮候室内 に移動した。人工気候室の側壁の内側には銀色の布製力 ーテンを掛けており、壁面の影響を極少にするエ夫をし ている。事前観測でグローブ温度計を用いた環境測定を 行っており、平均放射温度と気温が等しい条件学满足し ていることを確かめている。

被娭者の着衣状態は裸体(トランクスのみ)で、姿勢は、 市販の屋外用リクライニングシート上にて仰卧位とした。 但し、背面の接触面筫を最小にするために、身体を支持 するビニールバンドの幅を細くするなとの改良を加えた。 高温曝露なので安全のためにテンダーも同時に入室し被 涘者を観祭した。曝露時間は 60 分を目安としたが、被 梚者の全身が汗でぬれ十分な無效発汗を確認できるまで 䋊続した。結果的に平均禩露時間は 60 分であった。
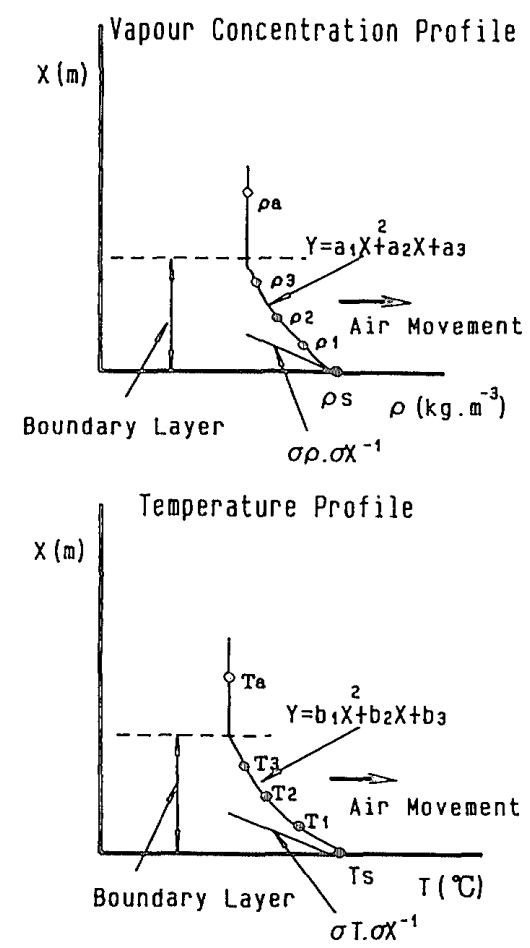

図2 皮䍙上の㵆度と絶対湿度のプロフィール 


\section{3-3. 実䮬結果}

(1)環境側条件

人工気候室内の温度/相対湿度を $4.8^{\circ} \mathrm{C} / 50 \%$ に設定 したが、実際の温度は $1 \sim 2{ }^{\circ} \mathrm{C}$ 低く、相対湿度も35〜 $45 \%$ 前後と低めでの制御となった。室内の風速は 0 . $1 \sim 0.2 \mathrm{~m} / \mathrm{s}$ であった。温度/相対湿度の結果を表 1 に示す。

(2)皮署温及び直腸温の経時変化

一例として、同一被㛟者の各部皮清温と直腸温を図 3 (a)〜 (c)に示す。前室での皮得温と直腸温はよく安定し ており、平均皮咸温は $34.8^{\circ} \mathrm{C}$ 的後、直腸温は $37 \sim$

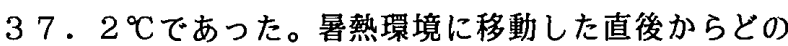
部位の皮觯温も迅速に上昇し、20分経過するまでは上 昇傾向はあるが $5 \sim 10$ 分間でほぼ安定に達した。安定 期の皮倜温は体幹部で高く $41^{\circ}{ }^{\circ} \mathrm{C}$ 前後であつたが、他は $38 \sim 39^{\circ} \mathrm{C}$ 範囲であった。直腸温は、全ての赛験で 暑熱曝露開始時に多少低下する傾向が見られた。これは、 低温曝露後に加温を開始した初期時に観察される血管拡 張による血流再分配 ${ }^{8)}$ が原因と思われる。20 分前後経 過してから曝露前の值に戻り、その後は一定の上昇率 ( $\left.1 \sim 1.2{ }^{\circ} \mathrm{C} / \mathrm{h} \mathrm{r}\right)$ で上昇した。

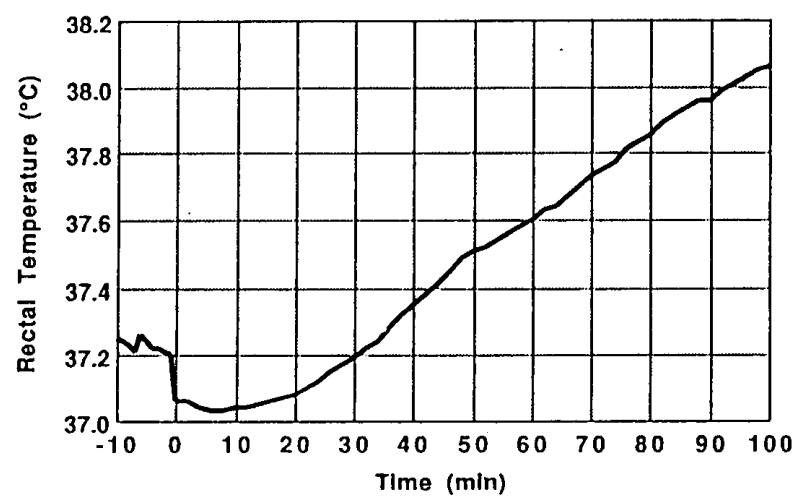

図 3 (a) 暑熱時の直腸温の変化

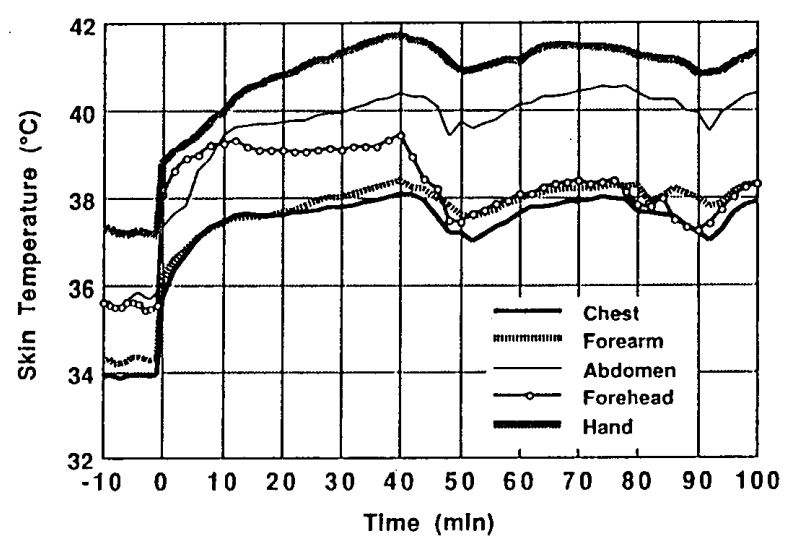

図 3 (b) 暑熱時の各部皮虐温の变化

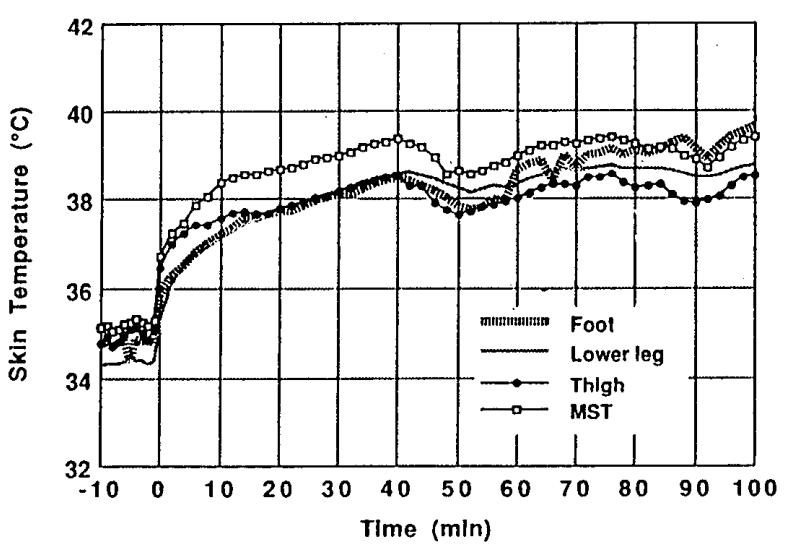

図 3 (c) 暑熱時0各部皮膚温と平均皮周温の変化

(3)局所発汗量と蒸汗量の経時変化

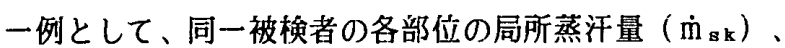

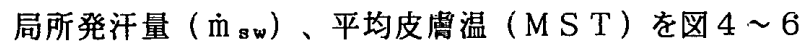
に示す。不感蒸泄域での発汗量と蒸汗量は部位による差 は余り見られず、発汗量がやや大きい値を示した。暑熱 瞋露後の発汗量と蒸汗量の上昇率は、部位による差が見 られたが、無効発汗が発現するまでは蒸汗量と発汗鲤の 上昇率は近似しており、前枷の上昇率が最も高く、胸部、 大腿前部の順に低くなる傾向が見られた。

(4)熱流量と対流放受熱量

図 7 に大腿前部での測定結果の一例を示す。熱流量の 平均值は前室で $60 \mathrm{k} \mathrm{cal} / \mathrm{m}^{2} \cdot \mathrm{h} \mathrm{r}$ 、署熱䀧露で-60 $\mathrm{kca} \ell / \mathrm{m}^{2} \cdot \mathrm{h} \mathrm{r}$ であった。移動後の変化は迅速で直ちに 安定する特徴を示した。また、局所力ロリメー夕で同部 位の対流放受熱量も算出した結果、 $\pm 10 \mathrm{kca} \ell / \mathrm{m}^{2} \cdot \mathrm{h}$ $r$ の值が得られ、自然対流域では放射による放受熱量の $20 \sim 25 \%$ 程度となる結果を得た。

(5)蒸発熱伝達率の算出

無効発汗は、胸や大腿で $30 \sim 40$ 分経過した時点で 発現した。図 4 〜 6の斜線部は無効発汗を示している。 例外なく無効発汗発現後の蒸汗量が減少しており、皮周 面上の汗の層による発汗抑制が㗢いたものと思われる ${ }^{9) 。 ~}$

曝露中に発汗量が蒸汗量より多くなった時点が皮署面 が完全にぬれた状態（局所ぬれ率＝1，0）と判断でき るので、その時の蒸汗量が臨界蒸汗量となる。困 4 に臨 界点と臨界蒸汗量を示した。臨界点での皮膚面と瓄境の 水蒸気圧差を求め局所蒸発熱伝達率を算出した結果を表 1 に示す。前腕の蒸発熱质達率 $\left(\mathrm{h}_{\mathbf{e}}, \mathrm{k} \mathrm{ca} \ell / \mathrm{m}^{2} \cdot \mathrm{h} \mathrm{r} \cdot\right.$ $\mathrm{mmHg}) の$ 值が大きく、大腿前部、胸部と順に小さくなる傾 向が確かめられた。

曝露中の発汗量と無効発汗量を表 2 に示す。本実験で は発汗量と無効発汗量を連続同時測定していないので、 正確に蒸汗效率（発汗量から無効発汗量を減じた值を発 


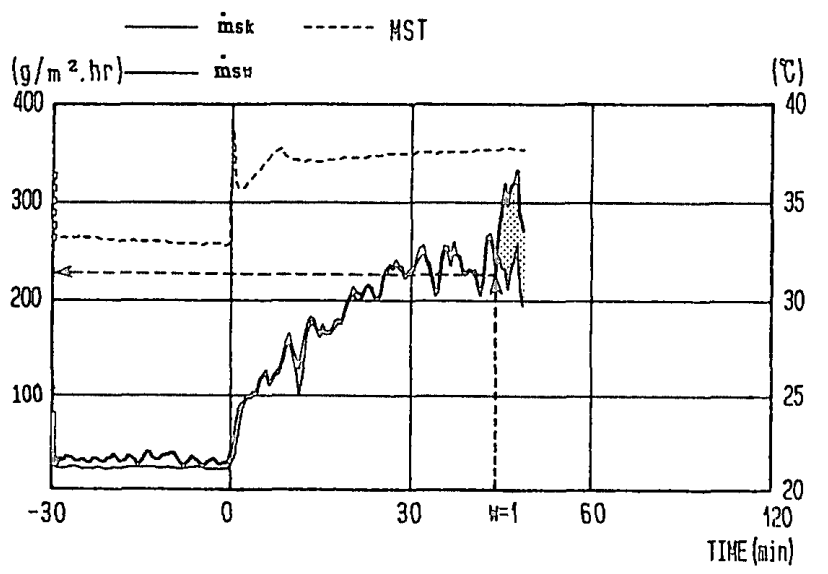

図4前䛷の蒸汗毁と発汗舅の変化

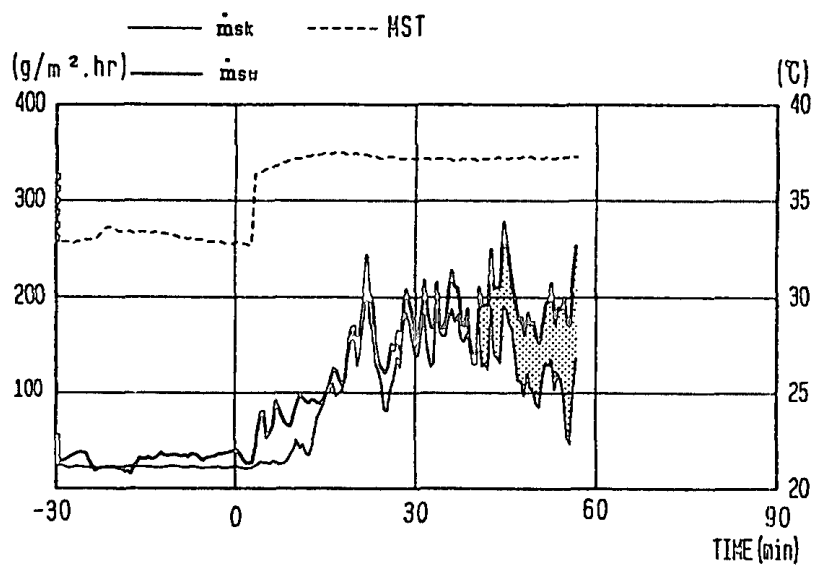

図 5 胸部の蒸汗是と発汗悬の变化

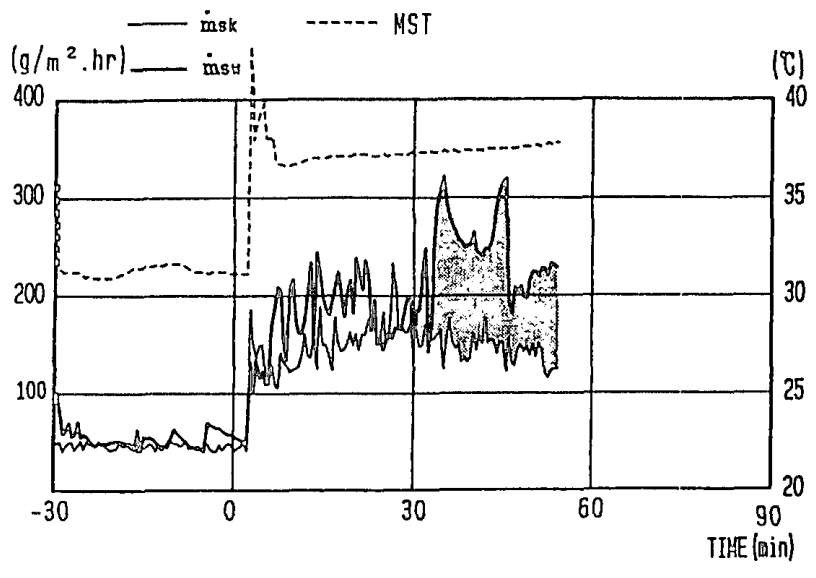

図 6 大腿的部の蒸汗量と発汗量の変化

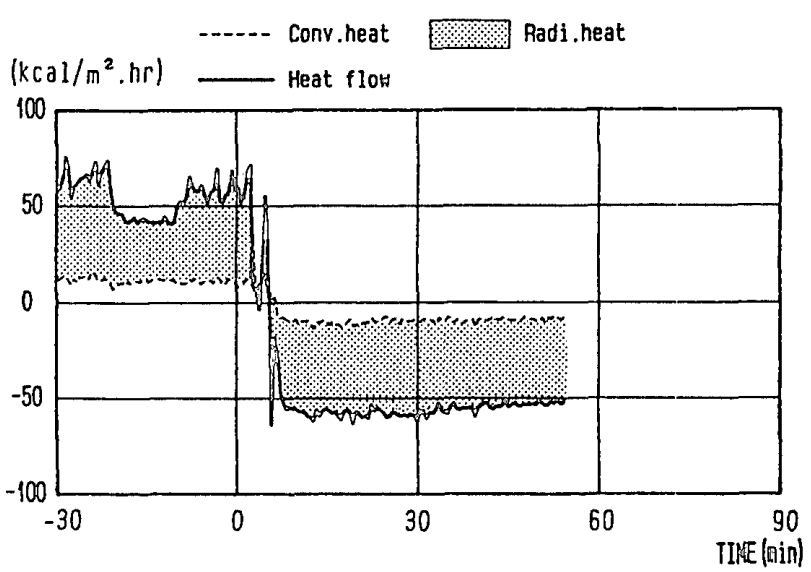

図 7 熱流量と局所対流放受熱量の変化

表 1 臨界蒸汗量から求めた局所蒸発熱公達率

\begin{tabular}{|c|c|c|c|c|c|c|}
\hline Subject & \multicolumn{3}{|c|}{ A } & \multicolumn{3}{|c|}{ B } \\
\hline Environ. factors & $46.9 \mathrm{C} / 39.6 \%$ & $46.2 \mathrm{C} / 37.5 \%$ & $46.8 \mathrm{C} / 35 \%$ & $45.9^{\circ} \mathrm{C} / 40.4 \%$ & $46.7 \mathrm{C} / 46.5 \%$ & $47.5 \mathrm{C} / 40.5 \%$ \\
\hline Observed site & chest $A$ & fornt thigh $\mathrm{A}$ & forearm $\mathrm{A}$ & chest $A$ & fornt thigh $A$ & forearm $\mathrm{R}$ \\
\hline $\begin{array}{l}\text { Critical evaporation } \\
\text { rate }\left(\mathrm{g} / \mathrm{m}^{2} . \mathrm{hr}\right)\end{array}$ & 454 & 212 & 273 & 469 & 462 & 225 \\
\hline $\begin{array}{l}\text { Vapor pressure } \\
\text { difference ( }(\mathrm{mm} \mathrm{Hg} \text { ) }\end{array}$ & 16.8 & 20.8 & 17.7 & 17.2 & 94.8 & 49.2 \\
\hline $\begin{array}{l}\text { Local evaporative heat } \\
\text { transfer coefficient } \\
\text { (kcal/m }{ }^{2} . \mathrm{hr} \cdot \mathrm{mmHg} \text { ) }\end{array}$ & 5.26 & 5.85 & 8.83 & 5.63 & 6.30 & 6.72 \\
\hline
\end{tabular}


表 2 体重減少量と無効発汗量

\begin{tabular}{|c|c|c|c|c|c|c|}
\hline Subject & \multicolumn{3}{|c|}{ A } & \multicolumn{3}{|c|}{ B } \\
\hline Environ. factors & $46.1 \mathrm{C} / 39.6 \%$ & $46.2 \mathrm{~T} / 37.5 \%$ & $46.8 \mathrm{C} / 35 \%$ & $45.9 \mathrm{C} / 40.4 \%$ & $46.7 \mathrm{C} / 46.5 \%$ & $47.5 \mathrm{C} / 40.5 \%$ \\
\hline Observed site & chest $R$ & fornt thigh $\mathrm{A}$ & forearm $\mathrm{R}$ & chest A & fornt thigh A & forearm $\mathrm{A}$ \\
\hline weight loss $\dot{\mathrm{m}} \mathrm{sw}(\mathrm{g}$ ) & 390 & 817 & 539 & 196 & 290 & 320 \\
\hline $\begin{array}{l}\text { Amount of sweat off } \\
\text { and on the skin midr (g) }\end{array}$ & 103 & 508 & 433 & 25 & 116 & 196 \\
\hline$\dot{\mathrm{m} d r} / \dot{\mathrm{m}} \mathrm{sw}$ & 0.26 & 0.62 & 0.80 & 0.13 & 0.40 & 0.61 \\
\hline
\end{tabular}

汗量で除した值）を求めることはできなかった。そこで、 参考として発汗量に対する無効発汗量の割台を比較する と、全ての実験で全身がめれた状態を確認したにもかか わらずかなりのばらつきが見られた。

\section{4. 考察}

局所の熱収支や温冷感は、全身のそれらを取り报う上 でもその重要性が認識されている。例えば、持田 ${ }^{10}$ )は局 所の対流熱伝達率から全身の対流熱伝達率を求める理論 的手法を提案しており、堀越ら ${ }^{11}$ は局所放射の影響を評 侮している。本研究では、暑熱時の局所発汗量と蒸汗量 を同時に測定することにより点汗量の臨界点を㨁接確認 できることと、その条件下で局所蒸発熱伝達率を算出で きることを提示した。以下に、関連する問題点について 考察する。

4-1. 局所経路別熱収支量を求めるための実験的手法

人体側から見ると熱流量は皮下組織内の层導による熱 量に等しく、環境倒から見ると対流と放射による放受熱 量の合計（乾性放受熱量）に等しい。全身レベルでの熱 収支の場合、両熱伝達率、平均皮層温と気温の差（放射 の場合は平均放射温度との差) が既知であれば経路別に 熱収支量を求められるので、放射や対流のそれ之れの影 晋を実䮖的に評洒できる。局所の場合は、乾性の放受熱 量を経路別に求めることが難しかったが、局所力ロリメ 一夕は境界首内の温度プロフィールも求められるので4) 圈 7 に示したように局所対流放受熱量も求められる。本 研究では、主に局所発汗量と蒸汗量の同時測定とその応 用について諭しているが、熱流計と局所カロリメータに よる局所の対流及び放射熱収支量も同時に求められる点 も実験手法として意義あるものと思われる。 4-2. 蒸発熱伝達率算出における問題点

熱収支理論に従えぼ、皮覑面の飽和水蒸気圧 $\left(\mathrm{p}_{\mathbf{s} \mathbf{k}}{ }^{*}\right.$, $m \mathrm{mHg})$ 、環境の水蒸気压 $\left(\mathrm{p}_{\mathrm{a}}, \mathrm{m} \mathrm{mHg}\right)$ 、ぬれ率 $(\omega)$ 又

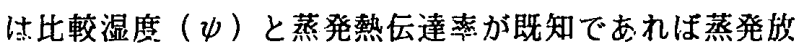

熱量 $\left(E_{s k}\right)$ は次式で算出できる。

$$
E_{s k}=h_{e} \times \omega \times\left(p_{s k}{ }^{*}-p_{a}\right)\left(\mathrm{kca} \ell / m^{2} \cdot h r\right)
$$

または、

$\mathrm{E}_{\mathbf{s k}}=\mathrm{h}_{\mathrm{e}} \times\left(\psi \times \mathrm{p}_{\mathrm{sk}}{ }^{*}-\mathrm{p}_{\mathrm{a}}\right)\left(\mathrm{kca} \ell / \mathrm{m}^{2} \cdot \mathrm{h} \mathrm{r}\right)(4)$ 皮曾面の水蒸気压は理論的にはぬれ率などを導入して 定義できるが、実際には皮畨面が完全にぬれている状態 でない限り既定することはできない。従って、人体の繁 発熱伝達率を求めるためには、皮膚面が完全にぬれてい ることを確認することが必須条件となる。N i s h i ら 12)は、暑熱時には食道温が急に上昇する臨界点を観察で きることを示しており、その現象は無効発汗により熱平 衡が維持できなくなったからと解釈した上で、間接的に 全身の皮周面が汗でぬれたことを確認できると報告して いる。一方、C a n d a s ら ${ }^{13}$ は、暑熱時の発汗量と無 効発汗量を同時に測定した結果から、蒸汗奻率が 0.6 以下にならないと皮盧面は完全にぬれた状態とはならな いことを確認している。本研究の目的はこれらの手法を 再確認することではないが、全身の場合、 $\omega=1$ ，0また は $\psi=1.00$ 状態を臨界点から判断し、その時点の資料 から蒸発熱伝達率を求める実駼的手法には問題があるこ と示唆したい。原因は臨界点以後の蒸汗量の抑制である。 本実験では、臨界点以後の蒸汗量が臨界点での蒸汗量 $60 \%$ \%で減少したケースがあった。全身の場合、最後 の部位が汗でぬれた時点が臨界点であるが、その時点で は他の部位で蒸汗量の抑制が生じていることを疑う余地 はない。環境と皮膚面の水蒸気压美は教わらないので、 求めた蒸発熱伝達率は過小評価される危唤性がある。 4-3. 非定常時の蒸発熱伝達率

強制対流領域では対流熱伝達も蒸発熱伝達も気流速が 支配的であるので、気流速が決まれば一意的に両熱伝達 率を求ることができる。皮望面と環境の水蒸気圧差の影 響は受け奞く、非定常時でもその値が変化する可能性注 少ない。しかし、室内環境ではむしろ自然对流領域に属 する場合が多い。K a k i t s u b a ら ${ }^{14}$ は、自然対流 領域では温度差に加えて水蒸気压差も物質移動の駆動力 
になることを証明している。温湿度条件が-.定の箸熱習 露時では、曝露後数分で平均皮同温は安定する。簡単の ために気温と平均皮放温か $36{ }^{\circ} \mathrm{C}$ を想定すると、初期時

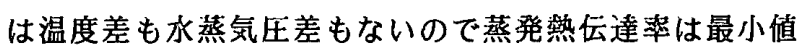
となる。しかし、皮剧面の承蒸気圧は、図8に示したよ うに皮而面が完全にぬれるまで時間と共に比較的緩漫に 上昇する。そこで、与えられた条件から等承蒸気压温度 差 (iso-vapor pressure temperature difference; $\Delta T p$ ) を算出した(算出方法の詳細は文献 14 を参照)。そして、 一段式 $\mathrm{h}_{\mathrm{e}}=\mathrm{k} \times \Delta \mathrm{T} \mathrm{p}^{0.25} \mathrm{k \textrm {k }}=4.5 \mathrm{kcal} / \mathrm{m}^{2} \cdot \mathrm{h} \mathrm{r}$ ・四Hgを代入してheの值を求めた結果を図8に示す。 $\psi=1$. 0 の時には $\triangle \mathrm{Tp}$ は $6{ }^{\circ} \mathrm{C}$ を越え、 heは $7 \mathrm{k} \mathrm{ca} \mathrm{\ell /}$ $\mathrm{m}^{2} \cdot \mathrm{h} \mathrm{r} \cdot \mathrm{mm} H$ 以上となる。この樣に、非定常時では $\mathrm{h}$ e の值が変化するので非定常での熱収支を取り扱う場合に 注意を要する。
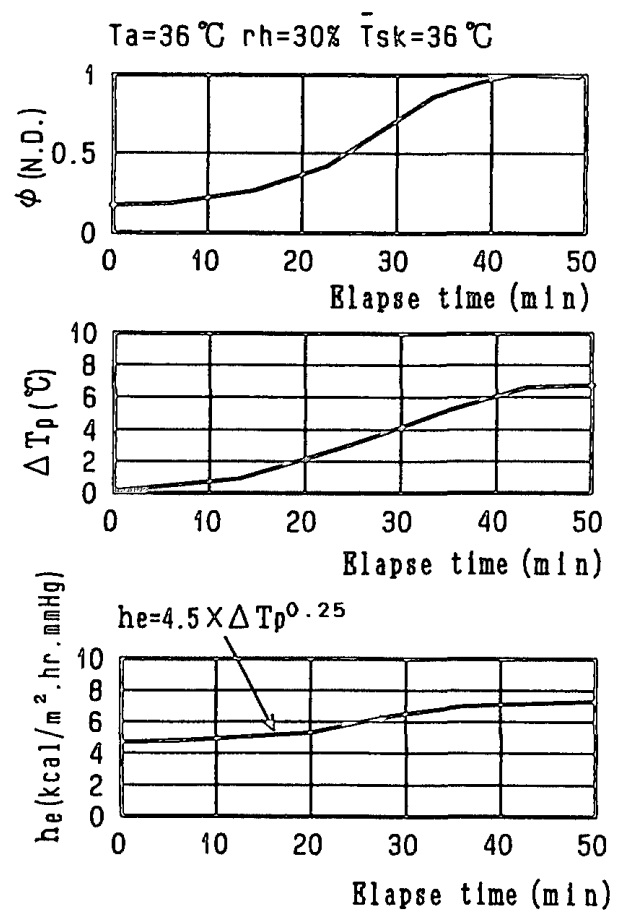

図 8 非定常時の蒸発熱伝達率

\section{謝辞}

今回の実駰に協力して頂いた干蕉大学工学部院生の李 侮房氏、富岡慶氏、田淵竜平氏に感謝の意を表します。

\section{参考文献}

1) Lamke, L. . , Nillson, C.E. and Reither, H.L.: Insensible perspiration from the skin under standardized environmental conditions, Linkoping Univ.Med.Dissertation, Vol.48:pp.II13-II21, 1977.

2) Lamke, L.0.:An instrument for estimating evaporation from small skin surfaces, Scand. J. Plast. Reconstr. Surg., Vol.5,pp.1-7,1970.1.
3) Kakitsuba, N.:Evaporative ratte from the skin surface in hyperbaric environments, SHASE Trans., Vo1.19:pp.59-69,1982.6.

4) Kakitsuba, N. and Katsuura, T.:Development of a ne日 device to measure local heat exchange by evaporation and convection, Avait. Space Environ. Med., Vol.63,pp.538-542,1992.6.

5) Nakayama, T. and Takagi, K.:Minute pattern of human perspiration observed by a continuously recording method,Jpn. J. Physiol.,Vo1.9,pp.359364,1959 .

6)Ohara,K.:Heat tolerance and sweating type,Nagoya Med. J., Vol.14,pp.133-144,1968.

7) 0gava, T.: Local determinants of sweat gland activity, In Advances in Climatic Physiol.,pp.93108, Igaku-shoin, 1972.

8) Hebb, P.:Afterdrop of body temperature during revarming from mild hypothermia in humans, $J$. App1. Physiol.,Vol.58,pp.4-13,1985.

9) Nade1,E.R. and Stoltijk, J.A.J.:Effect of skin Hettedness on sueat gland response,J. Appl. Phyiol., Vol.35(5),pp.689-694,1973.11.

10)持田徹: 人体に関する対流およびらく射熱云達率、日 本建築学会論文報告集、第 258 号、p p.63 69 昭和 52 年 8 月

11)堀越哲美 他 4 名:非対称および不均一熱放射環境の人. 体影瞕評価方法の研究、日本建築学会、第 413 号、 p p. $1 \sim 28$ 、平成 2 年 7 月

12) Nishi,Y.,Gonzalez,R.R. and Gagge,A.P.:Direct measurement of clothing heat transfer properties during sensible and insensible heat exchangewith the thermal environmnet,ASHRAE Trans., Vol.81(2),pp.183-199,1975.

13) Candas, V., Libert, J.P. and Vogt, J.J. :Human skin wettedness and evaporative efficiency of sueating,J. App1. Physiol.: Respirat. Environ. Exercise Physiol.,Vol.46(3),pp.522-528,1979.

14) Gakitsuba,N. and Bondi, H.R.: Heat transfer from the human body in hyperthermic, low gasvelocity environments, Aviat. Space Environ. Med., Vol.58, pp.227-236, 1987.3.

(1994 年1月 28 日原稿受理, 1994 年 8 月 25 日採用決定) 